\title{
Substitution of Wheat Flour with Nypa Flour to Characteristics Butter Cake and Acceptance of Panelist
}

\author{
Surhaini*, Gita D*, Mursyid* \\ ${ }^{\#}$ Technology of Agricultural Product Department, University of Jambi, Jambi \\ E-mail: surhaini@unja.ac.id
}

\begin{abstract}
Purpose the research to determine the effect substitution ofwheat flour with nypa flour to butter cake characteristics and acceptance of organoleptics test and to obstain the best formulation of nypa flour. This research used random completely design with consist of six treatment. Each treatment perform three replication to obstain eighteen units of experiment. The treatment use wereN1T1nypa flour $0 \%$ and $100 \%$ wheat flour; N2T2nypa flour $20 \%$ and wheat flour80\% N3T3nypa flour $40 \%$ and wheat flour $60 \%$ ;N4T4 nypa flour $60 \%$ and wheat flour $40 \%$.N5T5, nypa flour $80 \%$ and wheat flour $20 \%$, N6T6 nypa flour $100 \%$ and wheat flour $\mathbf{2 0 \%}$.. The result showed that used nypa flour significantly effect on water content, protein content, texture analyze, expand power, texture and the overall sensory was liked by panelist. The best treatment of substitution with wheat flour was N3T3 (wheat flour substitution with $40 \%$ flour nypa). The best butter cake with water content $12,17 \%$, protein content $5,69 \%$, texture $180,13 \mathrm{gF}$, expand power $31,44 \%$ and the best organoleptic with taste 5,00 (very like), and overall acceptance 4 (like).
\end{abstract}

Keywords:pounch cake, nypa flour, wheat flour

\section{INTRODUCTION}

Nypah (Nypafruticans) is one type of mangrove forest plant or grows in tidal areas. According to the Natural Resources Conservation Agency of Jambi Province Forestry Office (2013), the area of mangrove forests in Jambid Province is estimated to be $62,061 \mathrm{Ha}$ and it turns out that $30 \%$ of them become a place to grow nypah (Heriyanto et al, 2011). Nypha thrives in Mangrove areas in Jambi Province but underutilised. Several of nypa have been utilised such as leaves for thatching or roofing and nypa nira for making sugar. The nypa fruit have not been utilized yet. The fruit consist of shell and mesocard. Shell are promising biomass resources for biofuel and chemical. The mesocarp is promising to be exploited as food

Mesocarp of nypa contains diffrent amount of carbohydrate, protein, fat and ash depend on the growth location and the maturity of the fruit. Nypah has great potential when used properly. Ripe nypa fruit can be processed into nypah flour (Subiandono et al, 2011). Processing of ripenypah into flour because nypa contains carbohydrates that are high enough so that it can be used as an alternative food source (Fatriani et al, 2011).

Utilization of nypah flour as raw material for various food products has not been widely carried out because of the lack of public knowledge about the processing of nypa into flour.
Nypah fruit flour does not have gluten, so in the development of products made from nypa flour, products that do not need gluten development are chosen. One of the uses of nypah flour is to process it into a pounch cake.

Butter cake are one of the food products that are very popular among children, adults to the elderly (Windaryati, 2013). Brownies are made from raw flour with low protein content (Astawan, 2009). The development of brownies using nypah flour is expected to reduce the use of wheat flour.

The characteristic of pounch cake is solid and porous texture for example brownies, fruit cake, layer cake

Making butter cake using a variety of flour has been done. Silfia's research (2012), substitution of banana flour in making brownies up to $75 \%$ produced the best results with crude fiber content of $1.88 \%$, water content of $10.85 \%$, protein $12.09 \%$, texture, aroma and taste preferred by panelists . Setiawati et al (2015) explained the process of making brownies with the addition of coconut pulp powder up to $60 \%$ to produce good results with $7.44 \%$ fiber content, $32.08 \%$ fat content and $18.51 \%$ moisture content.

Making cake using a variety of flour has been done.

\section{MATERIAL AND METHODS}

Research was conducted at food analysis dan food prosessing laboratory in Agricultural technology faculty of Jambi 


\section{A. Material}

Nypa fruit were obstained from Tungkal Ilir district west Tanjung Jabung, Jambi Province. The fruit were harvested ripe which can be described to have dark brown skin color on top fruit, low protein flour, margarine, butter, chicken eggs,ovalet, cocoa powder, chocolate bars and sugar. The materials used for analysis were aquades, Na2SO4 anhydrous, concentrated $\mathrm{H} 2 \mathrm{~S} 04, \mathrm{HCl}$, indicators of phenolphetalin and $\mathrm{NaOH}$.

The tools used in this research for making nypah flour and butter cake are knives, glinders, mixers, analytic scales, electric ovens, sieves, stoves, pans, basins, baking paper, stirrers and mold tools. The tools used for analysis are cup, steven LFRA Texture Analizer, desiccator, pumpkin kjeldahl and calipers.

\section{Research Design and Statistical Analysis}

The research design used was a Completely Randomized Design (CRD) with five treatment levels and three replications so that 15 experimental units were obtained. The treatments given were substitution of nypah flour and wheat flour:

$\mathrm{P} 1=0 \%$ nypa flour : $100 \%$ wheat flour

$\mathrm{P} 2=20 \%$ nypa flour : $80 \%$ wheat flour

$\mathrm{P} 3=40 \%$ nypa flour : $60 \%$ wheat flour

$\mathrm{P} 4=60 \%$ nypa flour : $40 \%$ wheat flour

P5 $=80 \%$ nypa flour : $20 \%$ wheat flour

P6 $=100 \%$ nypa flour: $0 \%$ wheat flour

\section{B. Methods}

Ripe nypa flesh is separated from the fruit skin and then cleaned and washed with running water. Nypa is thinly sliced and then oven for 6 hours at $60 \mathrm{oC}$. After drying it is then crushed using a grinder and sieved with a 60 mesh sieve to become a nypa flour.

\section{Making Butter cake}

A total of 2 eggs were shaken using a mixer for 5 minutes, then added wheat flour and nypah flour according to treatment, ovalet, powdered chocolate and sugar. Margarine, butter and chocolate that have been thawed are put into the mixture and stirred until homogeneous. The dough is printed in a baking sheet that has been coated with baking paper, then baked using an oven at $160^{\circ} \mathrm{C}$ for 60 minutes.

\section{RESULT AND DISCUSSION}

\section{A. Water Content}

Analysis of variant showed that the use of nypah flour significantly affected the moisture content of butter cake. Table 1 showed that the real P1 formulation was higher than the formulations of P2, P3,P4, P5 and P6. The P3 formulation is not significantly different from $\mathrm{P} 4$ and $\mathrm{P} 5$ but is significantly lower than P1 and P2. P6 formulation was not significantly different from P5 but was significantly lower than P1, P2, P3 and P4. The average value of water content of nypah flour brownies ranged from $10.97 \%-15.23 \%$. The increasing use of nypah flour in the formulation, the lower the water content

According to Setyani (2017), low gluten content causes the release of water molecules when roasting is easy. Conversely, if high gluten content can cause the release of water molecules to be difficult. This is in accordance with Rachmawanti (2015) which states that wheat flour has gluten which can absorb water and bind larger water. While flour that does not have gluten is less able to bind water, then when roasting water content can vaporize

\section{B. Protein Content}

Analysis of variant showed that the use of nypah flour significantly affected protein content ofbutter cake as shown in table 1 . The higher flour nypa percentage in formulation tended to decrese content protein.

This assumed that wheat flour has a higher protein content than nypah flour. According to Ulyarti et al (2016), the protein content of nypah fruit flour is $5.98 \%$. While the protein content in wheat flour ranges from $8-13 \%$. When compared, the protein content in nypah flour is much lower.The difference between wheat flour and nypa flour is the gluten content which is not found in other flour. Gluten consists of gliadin and glutenin which is a component of protein which is only found in wheat .

\section{Texture Profile}

The results of variance analysis showed that the treatment of nypah flour and wheat flour significantly affected to the texture quality of butter cake. As shown in table 1 . Was found that increasing the nypa flour persentage resulted in significantly increased hardness and chewiness.

According to Wijayanti (2007), differences in level of butter cake hardness are influenced by volume. A good volume of butter cake has the desired development because the gas produced is held by gluten. Gluten will form a viscoelastic mass that binds all the ingredients of the mixture, especially starch into a mixture, the film layer formed is impermeable to the gas so that the gas can be trapped and form pores. The presence of pores causes the texture to become soft.

\section{Spesific Volume}

The results of the analysis of variance showed that the treatment of nypah flour and wheat flour significantly affected the value of specific volume. This shows that the more addition of nypah flour, the lower the spesific volume produced.

The decrease in specific volume of butter is caket to be caused by a reduced amount of gluten. Buckle (1987) stated that gluten is a sticky, sticky mass uniting the components of brownies to form a soft texture. According to Handayani (1987) the main components contained in flour that affect texture are protein. Proteins found in flour can form gluten when added with water, with gluten can cause the dough to be elastic and able to withstand gas. If the amount of gluten in the mixture causes a little less dough to hold the gas, the 
pores formed in the mixture are also small. As a result the mixture does not expand properly, then after burning is complete it will produce a hard product. Kusnandar (2010), states that the presence of gluten and glutelin mixing in food products can function to form an elastic and expanding dough, so that products that can expand and hollow can be obtained.

TABLE .1

AVERAGE VALUE OF WATER CONTENT, PROTEIN CONTENT, TEXTURE AND POWER TO DEVELOP NYPA FLOUR AND WHEAT FLOUR FORMULA

\begin{tabular}{ccccc}
\hline Nypa Flour : Wheat Flour & $\begin{array}{c}\text { Water } \\
\text { content } \\
(\%)\end{array}$ & $\begin{array}{c}\text { Protein content } \\
\mathbf{( \% )}\end{array}$ & $\begin{array}{c}\text { Texture } \\
\text { (gF) }\end{array}$ & Spesific Volume (\%) \\
\hline $0 \%: 100 \%$ & $15,23^{\mathrm{a}}$ & $6,12^{\mathrm{a}}$ & $129,67^{\mathrm{a}}$ & $59,49^{\mathrm{a}}$ \\
$20 \%: 80 \%$ & $13,92^{\mathrm{b}}$ & $5,91^{\mathrm{ab}}$ & $152,53^{\mathrm{ab}}$ & $49,61^{\mathrm{a}}$ \\
$40 \%: 60 \%$ & $12,17^{\mathrm{c}}$ & $5,69^{\mathrm{b}}$ & $180,13^{\mathrm{b}}$ & $31,44^{\mathrm{b}}$ \\
$60 \%: 40 \%$ & $11,95^{\mathrm{c}}$ & $5,37^{\mathrm{c}}$ & $181,20^{\mathrm{b}}$ & $25,81^{\mathrm{b}}$ \\
$80 \%: 20 \%$ & $11,27^{\mathrm{cd}}$ & $5,04^{\mathrm{d}}$ & $191,60^{\mathrm{c}}$ & $29,34^{\mathrm{b}}$ \\
$100 \%: 0 \%$ & $10,97^{\mathrm{d}}$ & $4,65^{\mathrm{e}}$ & $207,80^{\mathrm{d}}$ & $22,45^{\mathrm{b}}$ \\
\hline
\end{tabular}

Note :

The numbers followed by the same small letters in the same column are not significantly different at the level of 5\% according to the DNMRT test. The numbers followed by different lowercase letters in the same column are significantly different at the $5 \%$ level according to the DNMRT test

\section{E. Sensory Evaluation}

Variety analysis showed that using nypah flour in making brownies did not a significant affect on the taste.
The results of variance showed that the brownie ratio of wheat flour with nypah flour was not significantly different from the taste of the butter cake produced.This is presumably because the nypah flour has a bland taste

Taste

TABLE 2.

AVERAGE VALUE OF FLAVOUR AND OVERALL ACCEPTANCE OF BUTTER CAKE NYPAH FLOUR

\begin{tabular}{cccc} 
AND & Nypa flour (g) : wheat flour (g) & Taste & Overall acceptance \\
\cline { 2 - 4 } FLOUR & $0 \%: 100 \%$ & 4,85 & $3,65^{\mathrm{ab}}$ \\
$20 \%: 80 \%$ & 4,85 & $3,6^{\mathrm{ab}}$ \\
$40 \%: 60 \%$ & 5,05 & $4^{\mathrm{a}}$ \\
& $60 \%: 40 \%$ & 4,7 & $3,85^{\mathrm{ab}}$ \\
& $80 \%: 20 \%$ & 4,65 & $3,4^{\mathrm{bc}}$ \\
& $100 \%: 0 \%$ & 4,15 & $3^{\mathrm{c}}$ \\
\hline
\end{tabular}

WHEAT

Note: The numbers followed by the same lowercase letter in the same column are not significantly different at the level $5 \%$ according to the DNMRT test.

Scoring: The taste and Overall Acceptance: (1) Strongly dislike, (2) Dislike, (3) Somewhat likes, (4) likes, (5) Very likes

\section{Overall acceptence}

Analysis of variant showed that nypa flour and wheat flour formulation a significantly affected to overall accepteance. of butter cokies. Based on the organoleptic test the highest score was the wheat flour $60 \%$ and flour nypa $40 \%$.

\section{CONCLUSION}

The best treatment of substitution with wheat flour was N3T3 (wheat flour substitution with $40 \%$ flour nypa). The best butter cake with water content $12,17 \%$, protein content
$5,69 \%$, texture $180,13 \mathrm{gF}$, expand power $31,44 \%$ and the best organoleptic with taste 5,00 (very like), and overall acceptance 4 (like).

\section{REFERENCES}

AOAC. 1993. Official Method of Analysis. Association of Official Analysis Chemist. Washington, D.C., USA.

Andriani, D. 2012. Studi Pembuatan Bolu Kukus Tepung Pisang Raja (Musa paradisiaca L.). Skripsi Universitas Hasanuddin. Makassar.

Astawan, M. 2009. Panduan Karbohidrat Terlengkap. Dian Rakyat. Jakarta. 
Baer, AA dan Dilger, AC. 2014. Effect of Fat Quality On Sausage Processing, Texture and Sensory Characteristics. Meat Sience 96(3):1242-1249.

Fatriani, NMS dan Muhammad, NM. 2011. Rendemen Tepung Buah Nipah (Nypah fruticans) berdasarkan Jarak Tempat Tumbuh. Jurnal Hutan Tropis12(32) : 171-174.

Handayani, R. dan Siti A. 2011. Variasi Substitusi Rumput Laut Terhadap Kadar Serat dan Mutu Organoleptik Cake Rumput Laut (Eucheuma cottonii). Jurnal Pangan Dan Gizi 02(03).

Kusnandar, F. 2010. Kimia pangan. Komponen Pangan. PT. Dian Rakyat. Jakarta.

Osabor, V. N., Egbung, G. E. dan Okafor, P.C. Chemical Profile of NypaFructicans from Cross River Estuary, South Eastern Nigeria. 2008.Pakistan Journal of Nutrition 7 (1) : 146 - 150.

Rachmawanti, D., Achmad, R., Rizka, SK. 2016. Pengaruh Penambahan Tepung Koro pedag (Canavalia ensiformis) Termodifikasi sebagai Substirusi Tepung Terigu terhadap Karakteristik Kimia, Fisik dan Sensori Brownies Pangang.

Rahmiyati. 2006. Substitusi tepung terigu dengan tepung sagu dalam pembuatan mi kering. Skripsi Universitas Riau. Pekan baru.

Setyaningsih, D.,Anton, A dan Sari, MP. 2010. Analisa Sensori untuk Industri Pangan dan Agro. IPB Press. Bogor

Setyani, Sri., Siti, N., Ayu, DPP. 2017. Formulasi Tepung Tempe Jagung (Zea mays L.) dan Tepung Terigu Terhadap Sifat Kimia, Fisik dan Sensori Brownies Panggang. Jurnal Teknologi Industri dan Hasil Pertanian 22(2): 73-82.

Silfia. 2012. Pengaruh Substitusi Tepung Pisang Pada Pembuatan Brownies Terhadap Sifat Kimia dan Penerimaan Organoleptik. Jurnal Litbang Industri 2(2) : 71-78.

Subiandono E, Heriyanto, NM dan Endang, K. 2011. Potensi Nipah (Nypafruticans (Thumb) Wurmb) sebagai sumber pangan dari hutan mangrove. Buletin Plasma Nutfah 17(1) : 52-60.

Sudarmadji, S., Haryono, B dan Suhardi. 1997. Prosedur Analisa Untuk Bahan Makanan dan Pertanian. Liberty. Yogyakarta.

Ulyarti, Nazarudin dan Dian WS. 2017. The Study of Functional Properties of Nypafruticans Flour. International Conference on Chemistry, Chemical Process and Engineering : 1- 6.

Windaryati T., Herlina dan Ahmad, N. 2013. Karakteristik Brownies yang Dibuat dari Komposit Tepung Gembolo (Dioscorea bulbifera L.). Jurnal BerkalaIlmiah Pertanian 1(2) : $25-2$. 